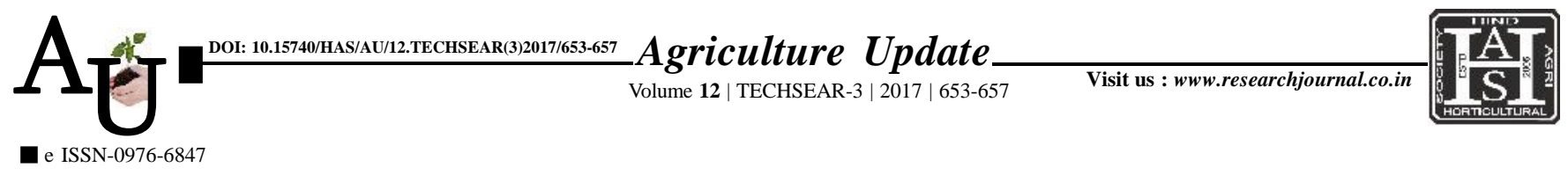

\title{
Research Article: Effect of tillage and integrated nutrient management on potassium fractions in Vertisol under rainfed cotton
}

\author{
KODURI MADHUKAR, O.S. RAKHONDE, E. SATYANARAYANA AND M. \\ SANTHOSH KUMAR
}

Article Chronicle: Received :

10.07.2017;

Accepted :

25.07.2017

KEY WoRds:

Potassium fractions, Integrated nutrient management, Conservationtillage, Potassium use efficiency, Contribution of nonexchangeable $\mathrm{K}$ to total $\mathrm{K}$ uptake

Author for correspondence :

\section{KODURI MADHUKAR}

Department of Soil

Science and Agricultural

Chemistry, Dr.

Panjabrao Deshmukh

Krishi Vidyapeeth, AKOLA (M.S.) INDIA

See end of the article for authors' affiliations
SUMMARY : The experiment was carried out at Research Farm of Department of Soil Science and Agriculture Chemistry, Dr. Panjabrao Deshmukh Krishi Vidyapeeth, Akola during Kharif 2015 to study the effect of tillage and integrated nutrient management on potassium fractions in Vertisol under rainfed cotton. The experiment was laid out in randomized block design with sixteen treatment combinations with three replications. The treatments consisted of tillage (conservation and conventional), integratednutrient management comprised of eight treatments involving FYM, crop residues, in situ green manuring of sunhemp, glyricidia leaf manuring in combination with inorganic fertilizers and 100 per cent $\mathrm{RDF}\left(60: 30: 30 \mathrm{~kg} \mathrm{~N}, \mathrm{P}_{2} \mathrm{O}_{5}\right.$ and $\left.\mathrm{K}_{2} \mathrm{O} \mathrm{ha}^{-1}\right)$. The results revealed that, the various treatments significantly increased the various forms of potassium.Significantly highest water soluble, exchangeable, lattice and total Kcontent of soil and highest potassium use efficiency was recorded with application of 50\% N through FYM + remaining RD through chemical fertilizers.Significantly highest percentage contribution to total potassium uptake by cotton was observed in the treatment with application of 100\% RDF (60:30:30 NPK kg ha' ${ }^{-1}$.

How to cite this article : Madhukar, Koduri, Rakhonde, O.S., Satyanarayana, E. and Kumar, M. Santhosh (2017). Effect of tillage and integrated nutrient management on potassium fractions in Vertisol under rainfed cotton. Agric. Update, 12(TECHSEAR-3) : 653-657; DOI: 10.15740/HAS/AU/12.TECHSEAR(3)2017/653657. 